\title{
UNIVERSITYOF BIRMINGHAM

\section{Modelling chemistry in the nocturnal boundary layer above tropical rainforest and a generalised effective nocturnal ozone deposition velocity for sub-ppbv NOx conditions}

\author{
Pugh, TAM; Ryder, J; Mackenzie, Angus; Moller, SJ; Lee, JD; Helfter, C; Nemitz, E; Lowe, D; \\ Hewitt, CN \\ DOI: \\ 10.1007/s10874-011-9183-4
}

Citation for published version (Harvard):

Pugh, TAM, Ryder, J, Mackenzie, A, Moller, SJ, Lee, JD, Helfter, C, Nemitz, E, Lowe, D \& Hewitt, CN 2010, 'Modelling chemistry in the nocturnal boundary layer above tropical rainforest and a generalised effective nocturnal ozone deposition velocity for sub-ppbv NOx conditions', Journal of Atmospheric Chemistry, vol. 65, no. 2-3, pp. 89-110. https://doi.org/10.1007/s10874-011-9183-4

Link to publication on Research at Birmingham portal

\footnotetext{
General rights

Unless a licence is specified above, all rights (including copyright and moral rights) in this document are retained by the authors and/or the copyright holders. The express permission of the copyright holder must be obtained for any use of this material other than for purposes permitted by law.

- Users may freely distribute the URL that is used to identify this publication.

- Users may download and/or print one copy of the publication from the University of Birmingham research portal for the purpose of private study or non-commercial research.

- User may use extracts from the document in line with the concept of 'fair dealing' under the Copyright, Designs and Patents Act 1988 (?)

- Users may not further distribute the material nor use it for the purposes of commercial gain.

Where a licence is displayed above, please note the terms and conditions of the licence govern your use of this document.

When citing, please reference the published version.

Take down policy

While the University of Birmingham exercises care and attention in making items available there are rare occasions when an item has been uploaded in error or has been deemed to be commercially or otherwise sensitive.

If you believe that this is the case for this document, please contact UBIRA@lists.bham.ac.uk providing details and we will remove access to the work immediately and investigate.
} 


\title{
Modelling chemistry in the nocturnal boundary layer above tropical rainforest and a generalised effective nocturnal ozone deposition velocity for sub-ppbv $\mathrm{NO}_{\mathrm{x}}$ conditions
}

\author{
T. A. M. Pugh*† J. Ryder ${ }^{\ddagger} \quad$ A. R. MacKenzie* \\ S. J. Moller ${ }^{\S}$ J. D. Leeף C. Helfter" ${ }^{\Uparrow}$ E. Nemitz" \\ D. Lowe** C. N. Hewitt*
}

This article is published in the Journal of Atmospheric Chemistry:

Pugh, T., Ryder, J., MacKenzie, A., Moller, S., Lee, J., Helfter, C., Nemitz, E., Lowe, D., and Hewitt, C.: Modelling chemistry in the nocturnal boundary layer above tropical rainforest and a generalised effective nocturnal ozone deposition velocity for sub-ppbv $\mathrm{NO}_{\mathrm{x}}$ conditions, Journal of Atmospheric Chemistry, 65, 89-110, doi:10.1007/s10874-011-9183-4, 2010.

\begin{abstract}
Measurements of atmospheric composition have been made over a remote rainforest landscape. A box model has previously been demonstrated to model the observed daytime chemistry well. However the box model is unable to explain the nocturnal measurements of relatively high [NO] and $\left[\mathrm{O}_{3}\right]$, but relatively low observed $\left[\mathrm{NO}_{2}\right]$. It is shown that a onedimensional (1-D) column model with simple $\mathrm{O}_{3}-\mathrm{NO}_{\mathrm{x}}$ chemistry and a simple representation of vertical transport is able to explain the observed nocturnal concentrations and predict the likely vertical profiles of these species in the nocturnal boundary layer (NBL). Concentrations of tracers carried over from the end of the night can affect the atmospheric chemistry of the following day. To ascertain the anomaly introduced by using the box model to represent the NBL, vertically-averaged NBL concentrations at the end of the night are compared between the 1-D model and the box model. It is found that, under low to medium $\left[\mathrm{NO}_{\mathrm{x}}\right]$ conditions

\footnotetext{
* Lancaster Environment Centre, Lancaster University, Lancaster, U.K.

${ }^{\dagger}$ correspondence to: t.pugh@lancs.ac.uk

$\ddagger$ Centre for Ecology and Hydrology, Penicuik, Midlothian, U.K. and University of Manchester, Manchester, U.K.

$\S$ Department of Chemistry, University of York, York, U.K.

INational Centre for Atmospheric Science, University of York, York, U.K.

${ }$ Centre for Ecology and Hydrology, Penicuik, Midlothian, U.K.

**University of Manchester, Manchester, U.K.
} 
$\left(\mathrm{NO}_{\mathrm{x}}<1 \mathrm{ppbv}\right)$, a simple parametrisation can be used to modify the box model deposition velocity of ozone, in order to achieve good agreement between the box and 1-D models for these end-of-night concentrations of $\mathrm{NO}_{\mathrm{x}}$ and $\mathrm{O}_{3}$. This parametrisation would could also be used in global climate-chemistry models with limited vertical resolution near the surface. Box-model results for the following day differ substantially if this effective nocturnal deposition velocity for ozone is implemented; for instance, there is a $9 \%$ increase in the following days peak ozone concentration. However under medium to high $\left[\mathrm{NO}_{\mathrm{x}}\right]$ conditions $\left(\mathrm{NO}_{\mathrm{x}}>1 \mathrm{ppbv}\right)$, the effect on the chemistry due to the vertical distribution of the species means no box model can adequately represent chemistry in the NBL without modifying reaction rate coefficients.

\section{Introduction}

Box modelling studies are frequently used to investigate daytime chemistry in the planetary boundary layer (PBL) (e.g. Aumont et al, 2003; Toyota et al, 2004; Hamer and Shallcross, 2007; Read et al, 2008; Pugh et al, 2010) because the computational expense can be focused on solving the chemistry rather than solving the atmospheric transport. Box models are appropriate during most daytime conditions (assuming the modelling domain is horizontally homogeneous on relevant advective timescales), as the rapid mixing within the PBL means that their critical assumption of instantaneous mixing throughout the model box is valid. As a result, box model output can be compared with point measurements made in the PBL during the day. In contrast, the nocturnal boundary layer (NBL) over land often assumes different characteristics. The lack of solar heating at the ground surface results in less energy in the system, and typically a lower boundary layer height than during the day. Often, particularly in the absence of a strong wind to induce mechanical turbulence, this lack of thermallyinduced turbulence leads to a statically stable NBL, with very limited mixing. The thermal effects are particularly important in the tropics where insolation is high and synoptic wind speeds are often low. Accordingly, under such conditions, very considerable gradients of species may exist in the NBL, meaning that point measurements may not be suitable for comparison with a box model representing the average NBL concentrations of the measured species. Furthermore, the ability of the box model to represent chemical and physical processes within the NBL may be compromised under statically stable conditions (e.g. Geyer and Stutz, 2004a; Galmarini et al, 1997).

This study compares results from the chemistry box model CiTTyCAT (Wild et al, 1996; Evans et al, 2000; Emmerson et al, 2004; Donovan et al, 2005; Real et al, 2007, 2008; Hewitt et al, 2009; Pugh et al, 2010) to measurements made above a remote tropical rainforest, and finds that the box model is unable to explain the unexpectedly high night-time concentrations of NO. A previous study with CiTTyCAT (Pugh et al, 2010) demonstrated that the box model could reproduce day-time chemistry, including $\mathrm{OH}$ and peroxy radical observations, reasonably well, particularly if inhomogeneous mixing (sometimes called segregation) was parametrised using an effective rate coefficient for the isoprene $+\mathrm{OH}$ reaction. First some background information on nocturnal $\mathrm{NO}_{\mathrm{x}}$ chemistry and modelling is reviewed in Section 2. The measurements are described in Section 3 and compared to the box model in Section 4, and reasons for the possible discrepancies are discussed. Section 5 demonstrates that a one-dimensional (1-D) column model can replicate the main features of the night-time measurements. Average 
NBL concentrations in the 1-D model are then compared with those in the box model to assess the extent to which the box model output deviates from that provided by the 1-D model. Section 6 then seeks to test whether the box model can be adapted to provide an adequate representation of the chemical evolution of the NBL, where adequate means, in this instance, sufficient to confirm known chemistry and sufficient to have a minimal impact on later daytime chemical evolution. A summary follows in Section 7 .

\section{$2 \quad \mathrm{NO}_{\mathrm{x}}$ and $\mathrm{O}_{3}$ in the $\mathrm{NBL}$}

Nocturnal $\mathrm{NO}_{\mathrm{x}}\left(\mathrm{NO}+\mathrm{NO}_{2}\right)$ partitioning in the remote boundary layer is typically strongly skewed in favour of $\mathrm{NO}_{2}$, in the absence of very high emission rates of NO. Very little $\mathrm{NO}$ is present due to its loss via $\mathrm{NO}+\mathrm{O}_{3} \rightarrow \mathrm{NO}_{2}+\mathrm{O}_{2}$ (R1) and the absence of $\mathrm{NO}_{2}$ photolysis via $\mathrm{NO}_{2}+h v \rightarrow \mathrm{NO}+\mathrm{O}\left({ }^{3} \mathrm{P}\right)(\mathrm{R} 2)$. In most situations above land, there is a surface emission of $\mathrm{NO}$, which can lead to a depletion of ozone in the nocturnal boundary layer (NBL) and an accumulation of $\mathrm{NO}_{2}$ over the course of the night. Other potentially important reactions are the formation of $\mathrm{NO}_{3}$ via $\mathrm{NO}_{2}$ $+\mathrm{O}_{3} \rightarrow \mathrm{NO}_{3}+\mathrm{O}_{2}(\mathrm{R} 3)$ and of $\mathrm{N}_{2} \mathrm{O}_{5}$ via $\mathrm{N}_{2} \mathrm{O}_{5}+\mathrm{M} \rightleftharpoons \mathrm{NO}_{2}+\mathrm{NO}_{3}+\mathrm{M}(\mathrm{R} 4)$. Both $\mathrm{NO}_{3}$ and $\mathrm{N}_{2} \mathrm{O}_{5}$ are unstable when exposed to photolytic flux, but during the night can act as stores or sinks (should they be deposited) of $\mathrm{NO}_{\mathrm{x}} . \mathrm{N}_{2} \mathrm{O}_{5}$ can be lost due to a heterogeneous reaction with water on the surface of aerosol particles via $\mathrm{N}_{2} \mathrm{O}_{5}+\mathrm{H}_{2} \mathrm{O}$ $\rightarrow 2 \mathrm{HNO}_{3}$ (R5). $\mathrm{NO}_{3}$ is lost by reaction with a range of species, but notably by $\mathrm{NO}_{3}$ $+\mathrm{NO}_{2} \rightarrow \mathrm{NO}+\mathrm{NO}_{2}+\mathrm{O}_{2}$ (R6). A comprehensive review of night-time chemistry is given by Wayne et al (1991) or Monks (2005). Dry deposition is also an important night-time sink for many species, particularly $\mathrm{NO}_{2}$ and $\mathrm{O}_{3}$. However deposition rates over vegetation, particularly for ozone, are often lower at night-time than during the day, as plant stomata tend to close at night. Wet deposition is not considered here as night-time rainfall was limited during the study period (Hewitt et al, 2010). For a more comprehensive review of biosphere-atmosphere exchange of reactive compounds the reader is referred to Fowler et al (2009).

Previous studies have shown success in representing night-time chemistry using one dimensional models. Hov (1983) investigated PBL chemistry using a 1-D Kprofile model and demonstrated that many species, particularly $\mathrm{NO}_{\mathrm{x}}$ and $\mathrm{O}_{3}$, should be expected to show marked vertical gradients in a stable NBL. NO in particular displays a high concentration layer close to its surface source under these conditions, whereas $\left[\mathrm{O}_{3}\right]$ typically has a minima at the ground due to dry deposition and NO titration, and features a positive gradient throughout the NBL. This typical pattern has been confirmed by several measurement studies, including Cros et al (1992), Pisano et al (1997), Gusten et al (1998), Glaser et al (2003), Stutz et al (2004), Geyer and Stutz (2004a) and Brown et al (2007).

Fitzjarrald and Lenschow (1983) and Gao and Wesely (1994) have shown that fluxes of reactive species, particularly $\mathrm{NO}, \mathrm{NO}_{2}, \mathrm{NO}_{3}$ and $\mathrm{N}_{2} \mathrm{O}_{5}$, can be modified by chemical reactions, such that the surface NO flux can be reduced by $80 \%$ at a height of $100 \mathrm{~m}$, even during daytime conditions. Such non-linear effects of chemistry on fluxes are not captured by K-profile models, and are usually solved using a secondorder closure model. Geyer and Stutz (2004a) developed the modified K model to take account of the effects of chemistry on flux. They applied their model to the case of $\mathrm{NO}_{\mathrm{x}}$ chemistry in the urban and rural NBL, finding that dry deposition often led to positive vertical gradients of $\mathrm{O}_{3}$ and $\mathrm{NO}_{2}$. The conclusions derived from their analysis 
were found to be in good agreement with field measurements of vertical profiles of $\mathrm{NO}, \mathrm{NO}_{2}$ and $\mathrm{O}_{3}$ by Stutz et al (2004), suggesting that such models can effectively represent NBL species profiles. Similar vertical profiles of $\mathrm{NO}_{2}$ and $\mathrm{O}_{3}$ were observed by Brown et al (2007). Gao and Wesely (1994) found that $\mathrm{NO}_{2}$ deposition at the surface could be enhanced due to an increase in $\left[\mathrm{NO}_{2}\right]$ near the surface NO source.

Galmarini et al (1997) used a 1-D model to study the evolution of $\mathrm{NO}_{\mathrm{x}}$ in the NBL, under moderate $\mathrm{NO}_{\mathrm{x}}$ mixing ratios of a few ppbv. They found substantial departures between a box model and the vertically averaged concentrations from the 1-D model for $\mathrm{NO}, \mathrm{NO}_{2}, \mathrm{NO}_{3}, \mathrm{~N}_{2} \mathrm{O}_{5}$ and $\mathrm{HNO}_{3}$, although $\mathrm{O}_{3}$ showed little deviation. Galmarini et al (1997) show that they can force the box model to accurately calculate the average NBL concentrations by utilising an effective reaction rate coefficient incorporating a term representing the subgrid effects. However the magnitude of the subgrid term will vary with the situation, requiring the effective rate coefficients to be revised for each new application using a 1-D model. Vinuesa and Vilà-Guerau de Arellano (2005) describe a similar method for the convective boundary layer.

To date, we know of no method which can improve the night-time performance of box models without requiring calibration for each case study (cf. Galmarini et al, 1997). In the analysis that follows, using a modified $\mathrm{K}$ model, it is shown that the vertical variations in night-time concentrations of $\mathrm{O}_{3}$ and $\mathrm{NO}_{\mathrm{x}}$ expected from the above-mentioned studies are consistent with measurements made at the OP3 rainforest site. A generalised parametrisation is then developed, which may be used to improve model estimation of daybreak concentrations of $\mathrm{O}_{3}$ for any site with similar low $\left[\mathrm{NO}_{\mathrm{x}}\right]$ characteristics. This parametrisation offers a method to incorporate the net result some of the complexities of NBL processes into a box (or indeed global) model, without requiring recalibration for each case study.

\section{Measurement description}

The OP3-Danum-08 field campaign was carried out in three phases during 2008: (i) ground-based measurements only, during April/May, (ii) a reduced set of flux and concentration measurements at a nearby oil palm estate during May/June, and (iii) both ground and aircraft measurements, during June/July. We focus here on measurements made during the first campaign, OP3-1.

A comprehensive suite of ground-based measurements of atmospheric composition were made at the Bukit Atur Global Atmosphere Watch station ( $4^{\circ} 58^{\prime} 59^{\prime \prime} \mathrm{N}$, $117^{\circ} 50^{\prime} 39^{\prime \prime} \mathrm{E}$ ) (Hewitt et al, 2010). This measurement site was situated at $437 \mathrm{~m}$ a.m.s.l., in a small (0.75 ha) grassy clearing, on a hill rising $\sim 260 \mathrm{~m}$ above the surrounding valley floor. The clearing is surrounded by secondary rainforest, rising to $\sim 10 \mathrm{~m}$ above the hilltop on three sides. A $100 \mathrm{~m}$ high, steel framed measurement tower was set in the centre of the clearing. A detailed description of the site is given in Hewitt et al (2010). This study concentrates on the measurements of $\mathrm{NO}, \mathrm{NO}_{2}$ and $\mathrm{O}_{3}$ made at $5 \mathrm{~m}$ above ground level at Bukit Atur. $\mathrm{NO}$ was measured directly by the chemiluminesence technique, $\mathrm{NO}_{2}$ was measured by conversion to $\mathrm{NO}$ via $\mathrm{UV}$ photolysis and subsequent detection of the NO by chemiluminesence and $\mathrm{O}_{3}$ was measured using a Thermo Electron Instrument (TEI) Model 49i UV Analyser. A detailed description of the measurements is given by Pike et al (2009). All three measurements were co-located. In addition, during OP3-3, gradient measurements of $\mathrm{O}_{3}$ were made at heights of $30,45,60$ and $75 \mathrm{~m}$ on the measurement tower using a TEI Model $49 \mathrm{C}$ UV photometric ozone analyser, with a precision of 1 ppbv. 

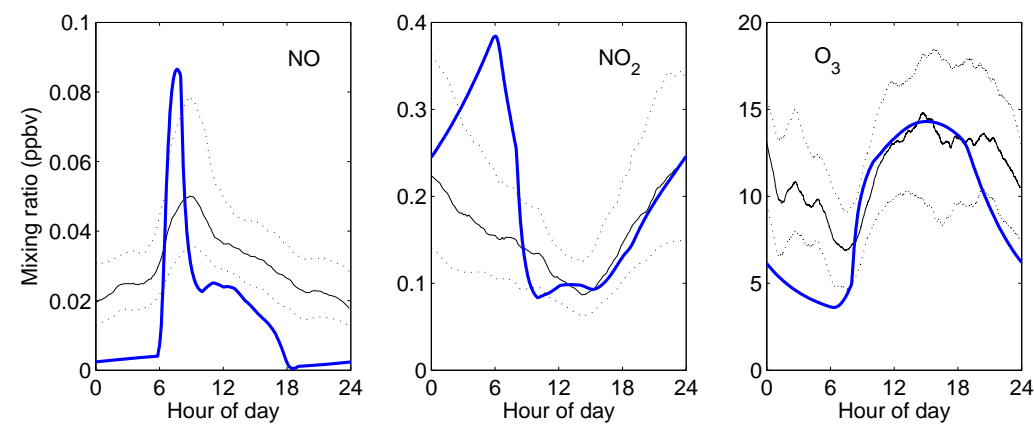

Figure 1: Solid black lines show median $\mathrm{NO}$ (left panel), $\mathrm{NO}_{2}$ (centre panel) and $\mathrm{O}_{3}$ (right panel) mixing ratios, measured at $5 \mathrm{~m}$ above ground at Bukit Atur during OP3-1, as a function of local time. Dotted lines show the upper and lower quartiles. The solid blue lines show the results of the standard CiTTyCAT run.

Measurements of night-time NO made at $5 \mathrm{~m}$ during the OP3 campaigns revealed substantial concentrations persisting throughout the night. Figure 1 shows that median measurements for OP3-1 give a fairly constant background NO mixing ratio of $\sim 20$ pptv. This is in contrast to previous studies of rural night-time chemistry, which have found very low mixing ratios of $\mathrm{NO}$, of the order of a few pptv (Biesenthal et al, 1998; Faloona et al, 2001; Mihele and Hastie, 2003). Median night-time $\mathrm{NO}_{2}$ mixing ratios remain relatively low, compared to these studies, at around 200 pptv.

\section{Box Modelling}

\subsection{Box model set-up}

The CiTTyCAT model was run in two-box mode as described in Pugh et al (2010). Between 0800 and 1800LT, when solar heating means the well-mixed assumption may be considered valid for the whole PBL, a single box is integrated over the height of the PBL (indicated to be $800 \mathrm{~m}$ by Dopplar LIDAR measurements, Pearson et al, 2010). However at 1800LT (sunset) the single box is split into two, with a lower box, representing the NBL, integrated up to $200 \mathrm{~m}$, and an upper box, representing the residual layer, integrated between $200 \mathrm{~m}$ and $800 \mathrm{~m}$. No mixing between these layers is allowed during the night; however, when turbulent mixing is re-initiated between 0800-1000LT the following morning (Pearson et al, 2010), the mixing height rises linearly to $800 \mathrm{~m}$ and the residual layer concentrations are gradually mixed into the lower box until the lower box has engulfed the residual layer. For details of the mixing parametrisation see Pugh et al (2010). No mixing vertically, out of the upper box, or laterally is permitted. This two layer model allows explicit consideration of the result of restricting the effect of emissions and deposition to a lower volume of atmosphere (the NBL) during the night. In the absence of appropriate measurements, the $200 \mathrm{~m}$ lower box height was selected by Pugh et al (2010) by comparing the results of model sensitivity studies with measured daytime concentrations. However, as the results of this study concentrate on comparisons between models, the most important factor is 
that a consistent height is chosen for all analysis.

Emissions of NO, isoprene and monoterpenes were prescribed following Pugh et al (2010) with 24-hour average fluxes corresponding to $5.6 \times 10^{9}$ and, $5.73 \times 10^{10}$ and 1.8 $\times 10^{10}$ molecules $\mathrm{cm}^{-2} \mathrm{~s}^{-1}$ respectively. Isoprene and monoterpene emissions follow a principally light-dependent cycle defined by the MEGAN algorithm (Guenther et al, 2006), whereas NO emissions are assumed constant. Dry deposition is included for $\mathrm{O}_{3}$, $\mathrm{NO}_{\mathrm{x}}, \mathrm{N}_{2} \mathrm{O}_{5}, \mathrm{HNO}_{3}, \mathrm{HNO}_{4}, \mathrm{H}_{2} \mathrm{O}_{2}, \mathrm{HCHO}, \mathrm{CH}_{3} \mathrm{CHO}, \mathrm{CH}_{3} \mathrm{OOH}, \mathrm{CH}_{3} \mathrm{CO}_{3} \mathrm{H}, \mathrm{PANs}$ and isoprene nitrates using the values listed in Evans et al (2000). The deposition velocity for isoprene nitrates is assumed to be as for $\mathrm{HNO}_{3}$, following Horowitz et al (2007). A sinusoidal diurnal variation is imposed as in Evans et al (2000), by multiplying the prescribed deposition velocity by a factor $s_{d}$, where

$$
s_{\mathrm{d}}=0.5+\left(0.5 \times \sin \left(15 \times\left(\mathrm{t}_{\mathrm{d}}-6\right)\right)\right),
$$

and $t_{d}$ is the time of day expressed in hours. This leads to an average night-time $\mathrm{V}_{\mathrm{d}\left(\mathrm{O}_{3}\right)}=0.6 \mathrm{~cm} \mathrm{~s}^{-1}$ over Bukit Atur. Wet deposition is applied for soluble species as in Pugh et al (2010).

\subsection{Comparison of box model with measurements}

Figure 1 shows the CiTTyCAT lower box concentrations as compared to the OP3-1 median measurement. A good agreement between model and measurements is achieved for the well-mixed period of the daytime (1000-1800LT) for $\mathrm{NO}_{2}, \mathrm{NO}$ and $\mathrm{O}_{3}$. Nighttime concentrations show very poor agreement; modelled night-time [NO] is $\sim 7 \times$ smaller than observations and night-time $\mathrm{NO}_{2}$ accumulates throughout the night to mixing ratios of over $500 \mathrm{pptv}$. The overestimation of modelled [NO] at sunrise is due to the photolysis of the overestimated night-time $\left[\mathrm{NO}_{2}\right]$ accumulation (R2). After 0800 LT, mixing in of low- $\mathrm{NO}_{2}$ air from the upper box rapidly decreases the $\mathrm{NO}_{2}$ mixing ratio in the lower box, eliminating the NO peak by 1000 LT.

There are two hypotheses that could explain these measurements, either (1) underestimation of the NO emission, or (2) limited mixing within the NBL causing the restriction of the high $\mathrm{NO}$ concentrations to a small region of the NBL, meaning that they are not representative of the average NBL concentration modelled by CiTTyCAT.

Hypothesis (1) is investigated by running CiTTyCAT with NO concentrations constrained to those measured. This leads to a huge build-up in night-time $\mathrm{NO}_{2}$ mixing ratios, in excess of $2 \mathrm{ppbv}$, demonstrating that simply increasing emissions cannot improve modelling of night-time $\left[\mathrm{NO}_{\mathrm{x}}\right]$. However, it is possible that some process, perhaps hitherto unrepresented in CiTTyCAT, could remove this excess $\mathrm{NO}_{2}$. Running CiTTyCAT with NO concentrations constrained to those measured and the $\mathrm{NO}_{2}$ deposition velocity set to the upper end of the range reported in the literature $(0.8$ $\mathrm{cm} \mathrm{s}^{-1}$ ), only leads to a 1 ppbv reduction in peak night-time $\mathrm{NO}_{2}$ to $1.7 \mathrm{ppbv}$. Setting $\mathrm{NO}_{2}$ deposition velocity equal to that used for $\mathrm{HNO}_{3}\left(2.0 \mathrm{~cm} \mathrm{~s}^{-1}\right)$ still results in peak $\left[\mathrm{NO}_{2}\right]$ four times the measurement. Therefore we rule out poor representation of $\mathrm{NO}_{2}$ deposition as a likely cause. We note that using a lower NBL height in the model would modify simultaneously both deposition velocities, and the volume throughout which emissions are diluted. Running CiTTyCAT with a lower box height reduced by $50 \%$ to $100 \mathrm{~m}$, improves the model fit to $[\mathrm{NO}]$, but, as above, overestimates $\left[\mathrm{NO}_{2}\right]$, whilst also worsening the fit for $\left[\mathrm{O}_{3}\right]$ by increasing $\mathrm{O}_{3}$ deposition.

Alternatively, the excess $\mathrm{NO}_{2}$ might be being sequestered chemically. Investigating all the reactions in CiTTyCAT capable of sequestering $\mathrm{NO}_{2}$ (See Supplementary 
Information) shows that either an increase in the rate coefficient by a magnitude much greater than the IUPAC reported uncertainty, or an increase in the concentration of the other reactant well beyond the measured concentration is required. Kleffmann et al (1998) and Kleffmann (2007) describe methods of HONO formation via the heterogeneous reaction of $\mathrm{NO}_{2}$ with either water or hydrocarbons. However measurements of HONO during OP3-3 indicated mixing ratios of less than 10 pptv (Pugh et al, 2010); much too small for HONO formation to provide the necessary $\mathrm{NO}_{2}$ sink. It is possible that some unknown process may be able to convert $\mathrm{NO}_{2}$ to $\mathrm{NO}$ in the absence of sunlight. NO will react with peroxy radicals, whose mixing ratios average 10 pptv during the night (Pugh et al, 2010). This will lead to $\mathrm{OH}$ formation, as observed in the night-time $\mathrm{OH}$ concentrations of $5 \times 10^{5}$ molecules $\mathrm{cm}^{-3}$. Therefore the measurements of $\mathrm{OH}$ and peroxy radicals made at $5 \mathrm{~m}$ are consistent with this hypothesis. However, if this process were occurring throughout the NBL, it would be expected that hydrocarbon concentrations would shown signs of oxidation occurring throughout the NBL. Isoprene concentrations at $5 \mathrm{~m}$, decrease on average throughout the night (C. Jones, pers. comm.), but isoprene concentrations at $75 \mathrm{~m}$ are much more stable, particularly in the period 0000 to $0600 \mathrm{LT}$, and also much higher than at $5 \mathrm{~m}$. This suggests that the conditions of night-time $\mathrm{OH}$ production, and hence the elevated NO concentrations, do not prevail throughout the boundary layer. Indeed the difference in isoprene concentrations at $5 \mathrm{~m}$ and $75 \mathrm{~m}$ suggests weak NBL mixing, supporting hypothesis (2).

Limited mixing within the NBL (hypothesis 2) could arise due to stable stratification of the NBL suppressing mixing during the night, leading to high [NO] near its surface source, as discussed in Section 2. Hypothesis (2) is tested in the next section using a 1-D model.

\section{1-D modelling}

\subsection{1-D model description and setup}

A gas-phase 1-D column model, based on MANIC (Microphysical Aerosol Numerical model Incorporating Chemistry) (described in Lowe et al, 2009; Ryder et al, 2010), has been used. This model is constructed using the Kinetic PreProcessor (KPP) (Damian et al, 2002; Sandu et al, 2003; Daescu et al, 2003). In this work the aerosol chemistry and microphysics features are not implemented, nor any of the in-canopy effects. Operator splitting is used to perform the chemistry and deposition procedures for each level in the column for one timestep, followed by the vertical transport for each species in the column. The approach is similar to earlier chemistry and transport models such as Gao et al (1993) and (ApSimon et al, 1994). The model consists of 58 boxes logarithmically distributed between 0 and $200 \mathrm{~m}$, according to the equation,

$$
z_{\text {top }}=\exp \left(\frac{l+13}{11.7}\right)-3
$$

where $z_{\text {top }}$ is the top of the level and $l$ is the level number. A simple chemistry scheme limited to $\mathrm{NO}_{\mathrm{x}}$ and $\mathrm{O}_{3}$ chemistry, is integrated within each box (Table 1). No photochemistry is included as all integrations in this study are performed at night. Radical chemistry, such as initiated by oxidation of terpenes, is neglected for simplicity. Deposition from the lowermost box is included for $\mathrm{O}_{3}, \mathrm{NO}_{2}$ and $\mathrm{HNO}_{3}$ at deposition 
velocities of $0.6,0.3$ and $2.3 \mathrm{~cm} \mathrm{~s}^{-1}$ respectively ${ }^{1}$, these being the average night-time deposition velocities used in CiTTyCAT following Evans et al (2000). Mixing between the boxes is parameterised using K-theory,

$$
j_{i}(z, t)=-K(z, t) \frac{\partial c_{i}(z, t)}{\partial z}
$$

where $K$ is a diffusion coefficient and $j_{i}$ is the vertical flux of a gas, $i$, whose concentration is given by $c_{i}$. Equation 3 is only valid for inert or slowly reacting gases because the effect of chemistry on the vertical flux of the gas is not considered (see e.g. Fitzjarrald and Lenschow, 1983; Brost et al, 1988; Vila-Guerau de Arellano, 2003). Geyer and Stutz (2004a) suggest a modified $K$ model in which,

$$
k_{i}(z, t)=K(z)\left(1+\frac{\frac{\partial\left(P_{i}(z, t)-L_{i}(z, t)\right)}{\partial z} \tau_{i e f f}(z, t)}{\frac{\partial c_{i}(z, t)}{\partial z}}\right)
$$

where $P_{i}$ and $L_{i}$ are chemical production and loss respectively and $\tau_{i e f f}$ is the effective timescale as approximated by Hamba (1987). Geyer and Stutz (2004a) found that it was sufficient only to apply the modified $K$ model for NO, and that approach has been taken here. $K$ was approximated via Monin-Obukhov similarity theory following Businger et al (1971) using,

$$
K(z, t)=\frac{\kappa u^{*}(t) z}{\Phi_{s}\left(\frac{z}{L}, t\right)}
$$

where $\kappa$ is the von Karman constant ( 0.38) and $u^{*}$ the friction velocity. The correction factor $\Phi$ for a stable atmosphere is defined by Seinfeld and Pandis (2006) as,

$$
\Phi\left(\frac{z}{L}, t\right)=1+4.7 \frac{z(t)}{L(t)}
$$

where $L$ is the Monin-Obukhov length. As OP3-1 campaign median measurements for $L$ and $u^{*}$ do not show a notable trend though the night, a single profile of $K$ is used during this period. The calculated $K$ profile is shown in Fig. 2, and is of a similar magnitude to, although slightly smaller than, that used by Geyer and Stutz (2004a). The lower quartile shows that there is considerable variation in this number throughout the night. The upper quartile is not shown as its value above $\sim 10 \mathrm{~m}$ is $>>1.0 \mathrm{~m}^{2} \mathrm{~s}^{-1}$, indicating that some relatively rapid transport events do occur during the night. These rapid transport events, which would cause short-lived perturbations to the steady-state profile, are not considered further in this analysis.

\subsection{Comparison of 1-D model with measurements}

Figure 3 shows the results of the 1-D model for the OP3-1 scenario, for 12 hours between 1800 and 0600LT, using the same inputs and initial conditions as CiTTyCAT. As expected, modelled NO concentrations are high near the ground, but tail-off quickly to very small (less than $1 \mathrm{pptv}$ ) concentrations above $\sim 30 \mathrm{~m}$. Conversely modelled $\left[\mathrm{O}_{3}\right]$ is depleted near the ground. Ozone loss near the surface could be either due to reaction with freshly-emitted NO (R1), or dry deposition. However the total number of NO molecules emitted overnight in the model $\left(2.4 \times 10^{14} \mathrm{~cm}^{-2}\right)$ is only $4 \%$ of the number of ozone molecules present in the NBL at sunset $\left(6.0 \times 10^{15} \mathrm{~cm}^{-2}\right)$, demonstrating

\footnotetext{
${ }^{1}$ In comparisons between the 1-D model and CiTTyCAT in section 6, these same deposition velocities are used in CiTTyCAT.
} 
Table 1: Chemical scheme for the 1-D model. Reaction rates for termolecular reactions are calculated using $k=\left(\frac{k_{0}[M]}{1+k_{0}[M] / k_{\infty}}\right) F^{\left(1+\left[\log _{10}\left(k_{0}[M] / k_{\infty}\right)\right]^{2}\right)^{-1}}$ where $M$ is the air density in molecules $\mathrm{cm}^{-3}$. $R$ is the universal gas constant and $T$ is temperature in Kelvin.

\begin{tabular}{|c|c|c|c|}
\hline Reactants & & Products & $\begin{array}{l}\text { Rate coefficient } \\
\left(\mathrm{cm}^{3} \text { molecule }{ }^{-1} \mathrm{~s}^{-1}\right)\end{array}$ \\
\hline $\mathrm{NO}+\mathrm{O}_{3}$ & $\rightarrow$ & $\mathrm{NO}_{2}+\mathrm{O}_{2}$ & $3.0 \times 10^{-12} \exp (-1500 / \mathrm{RT})$ \\
\hline $\mathrm{NO}+\mathrm{NO}_{3}$ & $\rightarrow$ & $2 \mathrm{NO}_{2}$ & $1.5 \times 10^{-11} \exp (170 / \mathrm{RT})$ \\
\hline $\mathrm{NO}_{2}+\mathrm{O}_{3}$ & $\rightarrow$ & $\mathrm{NO}_{3}+\mathrm{O}_{2}$ & $1.2 \times 10^{-13} \exp (-2450 / \mathrm{RT})$ \\
\hline $\mathrm{NO}_{2}+\mathrm{NO}_{3}+\mathrm{M}$ & $\rightarrow$ & $\mathrm{N}_{2} \mathrm{O}_{5}+\mathrm{M}$ & $\begin{array}{l}k_{0}=2.0 \times 10^{-30}(T / 300)^{-4.4} \\
k_{\infty}=1.4 \times 10^{-12}(T / 300)^{0.7} \\
F=0.6\end{array}$ \\
\hline $\mathrm{N}_{2} \mathrm{O}_{5}+\mathrm{M}$ & $\rightarrow$ & $\mathrm{NO}_{2}+\mathrm{NO}_{3}$ & $\begin{array}{l}\text { Coefficient of } \mathrm{NO}_{2}+\mathrm{NO}_{3}+\mathrm{M} \\
/ 2.7 \times 10^{-27} \exp (11000 / \mathrm{RT})\end{array}$ \\
\hline $\mathrm{NO}_{3}+\mathrm{NO}_{3}$ & $\rightarrow$ & $2 \mathrm{NO}_{2}+\mathrm{O}_{2}$ & $8.5 \times 10^{-13} \exp (-2450 / \mathrm{RT})$ \\
\hline $\mathrm{N}_{2} \mathrm{O}_{5}+\mathrm{H}_{2} \mathrm{O}$ & $\rightarrow$ & $2 \mathrm{HNO}_{3}$ & $2.6 \times 10^{-22}$ \\
\hline $\mathrm{CO}+\mathrm{NO}_{3}$ & $\rightarrow$ & $\mathrm{NO}_{2}+\mathrm{CO}_{2}$ & $3.03 \times 10^{-12} \exp (-446 / \mathrm{RT})$ \\
\hline $\mathrm{CO}+\mathrm{O}_{3}$ & $\rightarrow$ & $\mathrm{O}_{2}+\mathrm{CO}_{2}$ & $7.86 \times 10^{-15} \exp (-1913 / \mathrm{RT})$ \\
\hline
\end{tabular}

that in this scenario R1 is a relatively minor ozone sink compared to dry deposition. This conclusion is confirmed by the sensitivity studies carried out in this section (e.g. Fig. 5). The modelled gradient in ozone agrees well, in terms of shape, with gradient measurements made at the site during OP3-3 (black dots in Fig. 3). Modelling is not carried out here for OP3-3 because a localised NO leak, from one of the measurement instruments, makes the $\mathrm{NO}_{\mathrm{x}}$ measurements challenging to interpret in this context.

Modelled $\mathrm{NO}_{2}$ concentrations show a weak positive gradient near the ground, with a maximum between $3 \mathrm{~m}$ and $9 \mathrm{~m}$, followed by a clear negative gradient above this point. As $\mathrm{NO}_{2}$ is principally formed by reaction $\mathrm{R} 1$, it follows that $\mathrm{NO}_{2}$ is nearly all formed in the near-surface layer, but is then mixed upwards. Upward mixing prevents the build-up of high concentrations of $\mathrm{NO}_{2}$ seen when CiTTyCAT is constrained to the $5-\mathrm{m}[\mathrm{NO}]$ measurements. Figure 4 shows that the 1-D model is able to maintain a high 5 -m NO concentration throughout the night without producing an erroneously high $\mathrm{NO}_{2}$ concentration. The net flux of $\mathrm{NO}_{\mathrm{x}}$ through reaction (R4), taking into account the counteracting effect of the reverse reaction, is $0.7 \%$ of the $\mathrm{NO}_{\mathrm{x}}$ flux through $\mathrm{R} 1$, showing that reaction R4 is of minor significance at these relatively low (in global terms) concentrations of $\mathrm{NO}_{\mathrm{x}}$. The night-time and vertically averaged mixing ratios of $\mathrm{NO}_{3}$ and $\mathrm{N}_{2} \mathrm{O}_{5}$ are 0.1 pptv and 0.03 pptv respectively.

Although the 1-D model results above support the stratification hypothesis described in section 4.2, Fig. 4 shows that the 1-D model calculations do not match the magnitude of the OP3-1 measurements: modelled $\mathrm{NO}$ and $\mathrm{NO}_{2}$ concentrations at $5 \mathrm{~m}$ are too high, and the $\mathrm{O}_{3}$ concentration is too low. There are several factors which may be responsible for this disagreement, including the rate of mixing, emission and deposition. These factors are investigated through sensitivity studies, which are summarised below. The impact of the reduced chemical complexity in the 1-D model, as compared to CiTTyCAT, is found to be not important for this study (see 


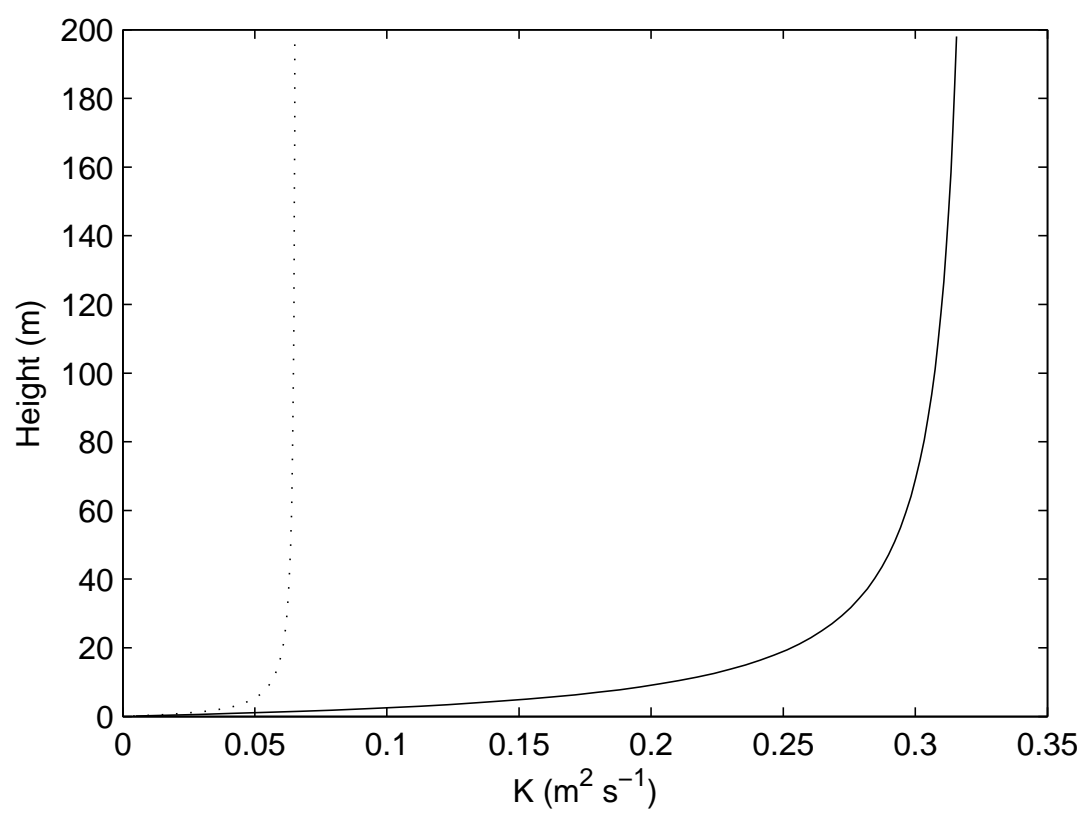

Figure 2: OP3-1 median profile of the diffusion coefficient, $\mathrm{K}$, with height averaged throughout the night. The dotted line shows the low quartile of the night-time average.

Supplementary Information).

The model-measurement agreement for $\mathrm{NO}_{x}$ and $\mathrm{O}_{3}$ is largely insensitive to the K-profile used. Doubling $K$ results in a slightly more uniform tracer profile with height, whilst halving $K$ accentuates the peaks. However, the profiles remain similar to those in Fig. 3. The $\mathrm{NO}_{2}$ deposition rate also has a limited effect on the modelmeasurement agreement. In order to bring modelled 5-m $\left[\mathrm{NO}_{2}\right]$ into agreement with the measurements an increase in the $\mathrm{NO}_{2}$ deposition velocity from $0.3 \mathrm{~cm} \mathrm{~s}^{-1}$ to 4.0 $\mathrm{cm} \mathrm{s}^{-1}$ is required. In the context of literature values for night-time $\mathrm{NO}_{2}$ deposition velocity of $0.1-0.8 \mathrm{~cm} \mathrm{~s}^{-1}$ (Wesely and Hicks, 2000; Watt et al, 2004; Michou et al, 2005; Trebs et al, 2006; Zhang et al, 2009), increasing the $\mathrm{NO}_{2}$ deposition rate is not an appropriate method with which to improve the model fit to $5-\mathrm{m}\left[\mathrm{NO}_{2}\right]$ measurements. In contrast, reducing the model ozone deposition velocity to the lower end of the literature range of $0.1-0.6 \mathrm{~cm} \mathrm{~s}^{-1}$ (Fan et al, 1990; Wesely and Hicks, 2000; Matsuda et al, 2005; Michou et al, 2005; Coyle et al, 2006; Kerkweg et al, 2006; Rummel et al, 2007), brings 5-m modelled concentrations of $\mathrm{O}_{3}$ and $\mathrm{NO}$ into excellent agreement with the observations.

The NO emission rate used above of $5.6 \times 10^{9}$ molecules $\mathrm{cm}^{-2} \mathrm{~s}^{-1}$, estimated using CiTTyCAT by Pugh et al (2010), was optimised using 1000-1800 LT measurements, when the boundary layer could be considered well-mixed. In a well-mixed boundary layer, concentrations at any one point would be influenced by a relatively large emission footprint. In contrast, the NO measurements made at $5 \mathrm{~m}$ in the stratified night-time 

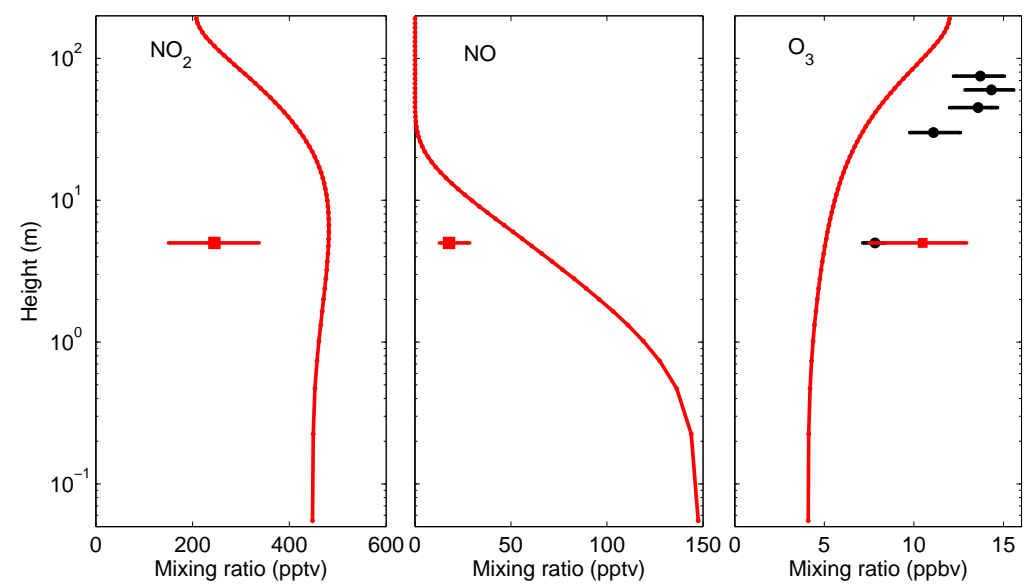

Figure 3: 1-D model vertical profile at midnight (red line, each level output marked by dots) and OP3-1 median 5-m measurements at that time (red squares, upper and lower quartiles shown by bars). Gradient measurements of median ozone concentration made during OP3-3 are shown (black dots, upper and lower quartiles shown by bars) to compare the profile shapes (note that the magnitude of OP3-3 concentrations is not directly comparable to those from OP3-1).
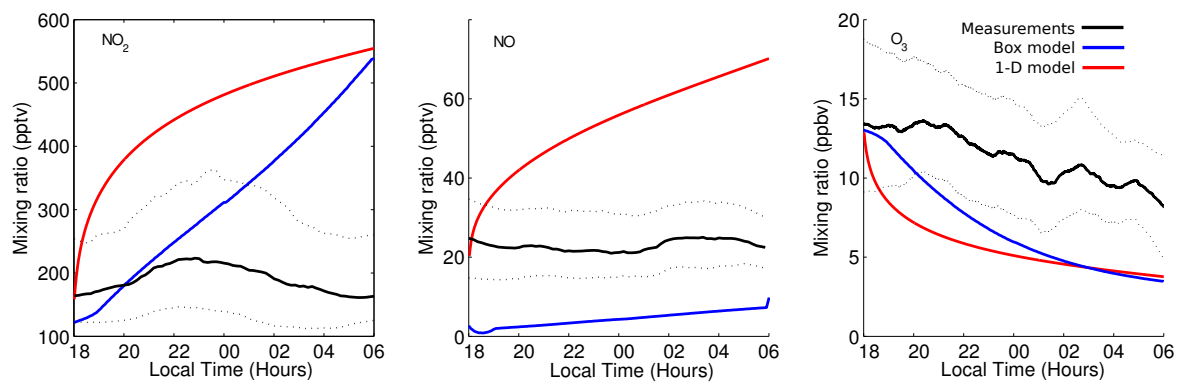

Figure 4: Comparison of 1-D model output at $5 \mathrm{~m}$ throughout the night (red line) against OP3-1 median 5-m measurements (black line, upper and lower quartiles shown by dots). CiTTyCAT lower-box output over the same time is shown by the blue line. 


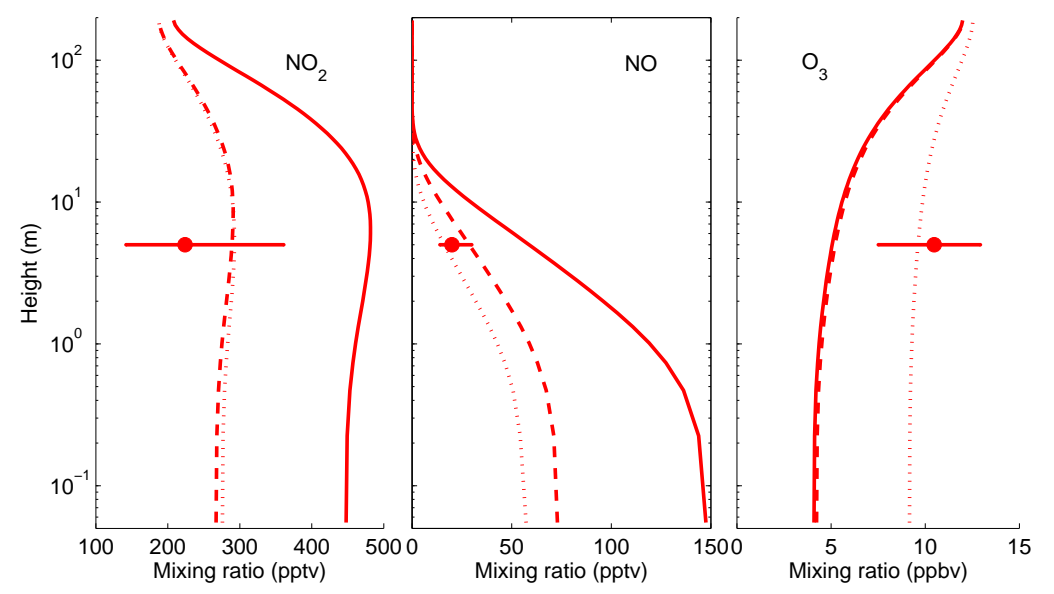

Figure 5: Comparison of measurements (large dot) against model 6 hour (midnight) concentrations with standard NO emission (solid line), NO emission reduced by $50 \%$ (dashed line), and NO emission reduced by $50 \%$ and $V_{d(\mathrm{O} 3)}=0.1$ $\mathrm{cm} \mathrm{s}^{-1}$ (dotted line).

boundary layer at Bukit Atur are likely to have a much smaller emission footprint, most likely with a different NO emission potential as a result of local heterogeneities. Furthermore, diurnal temperature variations could result in a smaller NO flux at night (Yienger and Levy, 1995). Figures 5 and 6 show the effect of reducing the NO emission by $50 \%$, which brings model and measurements much more into line with regard to NO and $\mathrm{NO}_{2}$ concentrations. Combining the $\mathrm{NO}$ emission decrease with an $\mathrm{O}_{3}$ deposition velocity of $0.1 \mathrm{~cm} \mathrm{~s}^{-1}$ generates a model output within variability of measurements of $\mathrm{NO}, \mathrm{NO}_{2}$ and $\mathrm{O}_{3}$ throughout most of the night.

Intermittent nocturnal mixing events (e.g. Fitzjarrald and Moore, 1990; Acevedo et al, 2006) provide an alternative explanation to the model-measurement discrepancy for $\mathrm{NO}_{\mathrm{x}}$ and $\mathrm{O}_{3}$, with the residual layer most likely providing a sink for $\mathrm{NBL} \mathrm{NO}_{\mathrm{x}}$ and a source for $\mathrm{NBL} \mathrm{O}_{3}$. An increase in nocturnal mixing events could also explain the turnover in $\left[\mathrm{NO}_{2}\right]$ after midnight. However, the NBL height used here was optimised by Pugh et al (2010) using measured tracer concentrations. Therefore, the average effect of such mixing events have effectively been incorporated into their calculation of the $200 \mathrm{~m}$ NBL height. This approach was also adopted by Strong et al (2009). Nonetheless, despite the failure of the simple 1-D model used here to capture all the complexities of the situation, the results demonstrate that the measured night-time concentrations at $5 \mathrm{~m}$ can be explained by the stratification hypothesis and therefore it is critical to consider stratification and limited mixing when comparing with night-time measurements at this site. 

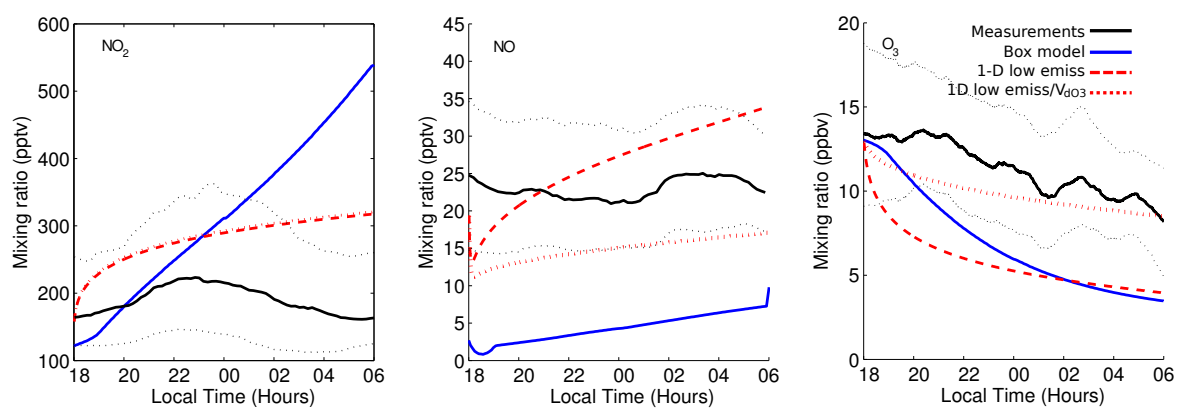

Figure 6: Timeseries comparison of 5-m OP3-1 median measurements (black solid line, upper and lower quartiles shown by black dotted line) against 1D model 5 -m concentrations with NO emission reduced by $50 \%$ (red dashed line) and NO emission reduced by $50 \%$ and $V_{d(O 3)}=0.1 \mathrm{~cm} \mathrm{~s}^{-1}$ (red dotted line). CiTTyCAT lower-box output over the same time is shown by the blue line.

\section{Comparing box and 1-D models in the NBL}

A 1-D model is able to produce a better fit to the measured nocturnal concentrations of $\mathrm{NO}_{\mathrm{x}}$ and $\mathrm{O}_{3}$ at $5 \mathrm{~m}$, compared to the CiTTyCAT box model. However, as box models are typically used for modelling daytime tracer concentrations, a pertinent question is how well can CiTTyCAT calculate vertically-averaged NBL concentrations at the end of the night? As the end-of-night concentrations effectively provide the initial conditions for the chemistry during the day, failing to model these daybreak concentrations is likely to result in inaccuracies in daytime chemistry, particularly in the morning. To address this question CiTTyCAT and the 1-D model were run with a NBL height of $200 \mathrm{~m}$. Emissions of $\mathrm{NO}$ and deposition velocities were equalised between the two models to the average night-time values used in the CiTTyCAT run in Section 4 of $5.6 \times 10^{9}$ molecules $\mathrm{NO} \mathrm{cm}{ }^{-2} \mathrm{~s}^{-1}, V_{d N O_{2}}=0.3 \mathrm{~cm} \mathrm{~s}^{-1}, V_{d O_{3}}=0.6 \mathrm{~cm} \mathrm{~s}^{-1}$ and $V_{d \mathrm{HNO}_{3}}=2.3 \mathrm{~cm} \mathrm{~s}^{-1}$. Note that the emission and deposition rates from Section 5.2 are not used here, as the intention is to test the daytime-optimised CiTTyCAT setup. Both models were initialised with average measured 1800 LT concentrations (see Supplementary Information) and run for 12 hours until daybreak.

It has been shown (e.g. Hov, 1983; Fitzjarrald and Lenschow, 1983; Thompson and Lenschow, 1984; Gao and Wesely, 1994; Geyer and Stutz, 2004a), that in the presence of a NO concentration substantially greater than that observed during OP3, the titration of $\mathrm{O}_{3}$ by $\mathrm{NO}(\mathrm{R} 1)$ can have very large effects on $\mathrm{O}_{3}$ and $\mathrm{NO}_{2}$ concentrations, whilst also preventing enough $\mathrm{O}_{3}$ and $\mathrm{NO}_{2}$ reaching the surface to generate a notable deposition flux. In order to understand whether the results produced by this model comparison are limited to the low $\left[\mathrm{NO}_{\mathrm{x}}\right]$ conditions encountered during OP3, the comparison is also carried for medium and high $\left[\mathrm{NO}_{\mathrm{x}}\right]$ conditions, as might be encountered at other locations.

\subsection{Low $\left[\mathrm{NO}_{\mathrm{x}}\right]$ conditions}

The average integrated NBL concentrations at daybreak (0600 LT) are compared in Fig. 7. $\mathrm{NO}$ and $\mathrm{NO}_{2}$ mixing ratios show very close agreement. The close inter-model 


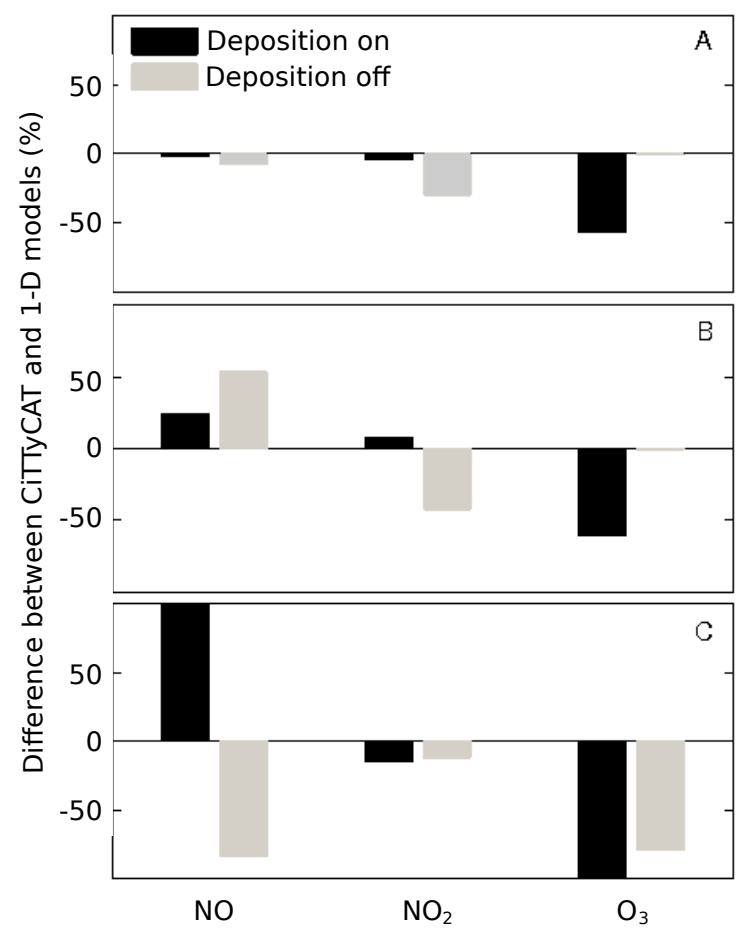

Figure 7: Percentage difference between CiTTyCAT and the 1-D model for vertically averaged NBL concentrations at daybreak ((CiTTyCAT - 1D)/1D) $\times 100)$. Deposition on uses dry deposition velocities as specified at the start of this section. Deposition off sets all dry deposition velocities to zero. Plates A, $\mathrm{B}$ and $\mathrm{C}$ show runs with NO emissions of $5.6 \times 10^{9}, 5.6 \times 10^{10}$ and $5.6 \times 10^{11}$ molecules $\mathrm{cm}^{-2} \mathrm{~s}^{-1}$ respectively.

agreement for $\mathrm{NO}_{2}$ is somewhat unexpected as the $\mathrm{NO}_{2}$ deposition velocity is not insubstantial and $\mathrm{NO}_{2}$ displays a clear concentration maximum close to the ground in the 1-D model, leading to an expectation of lower $\left[\mathrm{NO}_{2}\right]$ in the 1-D model. However $\mathrm{NO}_{2}$ is mainly formed in the lowest $30 \mathrm{~m}$, where substantial concentrations of $\mathrm{NO}$ exist. The K-profile (Fig. 2) shows that transport upwards, away from the deposition sink, is much more rapid than transport downwards towards the deposition sink, especially in the lowermost part of the NBL.

In contrast to the close inter-model agreement for $\mathrm{NO}_{\mathrm{x}}$ species, the CiTTyCAT ozone mixing ratio is $57 \%$ smaller than the ozone mixing ratio in the 1-D model. The 1-D model surface ozone concentration is actually very close to that generated by CiTTyCAT, but the $\mathrm{O}_{3}$ deposition flux in the 1-D model is reduced by the slow transport to the surface, leaving much higher $\mathrm{O}_{3}$ concentrations at upper levels. Unlike $\mathrm{NO}_{2}$, ozone does not have a night-time source in the NBL. The importance of deposition is 
demonstrated in Fig. 7, by carrying out identical runs with each model with deposition turned off. Good agreement is then found between the 1-D model and CiTTyCAT for $\mathrm{NO}, \mathrm{NO}_{\mathrm{y}}$ and $\mathrm{O}_{3}$. The apparent poor agreement for $\mathrm{NO}_{2}$ is due to the formation of isoprene nitrates in CiTTyCAT and may be ignored for the purposes of this analysis (see Supplementary Information).

Sensitivity tests were carried out, varying the ozone deposition velocity in CiTTy$\mathrm{CAT}$ in order to attain the best possible agreement of CiTTyCAT and 1-D model $\mathrm{O}_{3}$ concentrations. As there is only one independent variable, optimisation was carried out by eye until a clear best fit was found. This best fit was achieved using a reduced $\mathrm{O}_{3}$ deposition velocity of $0.21 \mathrm{~cm} \mathrm{~s}^{-1}$; a change of $-65 \%$.. This change yields only a small reduction in $\mathrm{NO}_{2}$ mixing ratio to 344 pptv, but suppresses the $\mathrm{NO}$ mixing ratio to 2.66 pptv. However, because of the short chemical lifetime of $\mathrm{NO}$, the concentrations of NO carried over to the following day are not of great consequence.

The high NO concentrations seen near the ground in the 1-D model will modify night-time radical chemistry near the surface. A study of this is beyond the scope of this work. In a study of the vertical variability of night-time $\mathrm{HO}_{\mathrm{x}}$ chemistry, Geyer and Stutz (2004b) found that elevated [NO] near the surface resulted in a substantial production of $\mathrm{HO}_{\mathrm{x}}$ when VOCs were present. However, this scenario contained NO concentrations an order of magnitude larger than modelled here for OP3-1, and it is not expected that night-time radical chemistry caused by a near-surface build-up of $\mathrm{NO}$ will have an important effect on overall NBL oxidation for this low- $\left[\mathrm{NO}_{\mathrm{x}}\right]$ scenario. Hence, whilst it may be concluded that it is not possible to change the set-up of the CiTTyCAT parameters to exactly replicate the 1-D model concentrations in the NBL, paying careful consideration to the night-time deposition velocity assignment in box models to take account of the variation in concentration across the NBL, may produce $\mathrm{NO}_{2}$ and $\mathrm{O}_{3}$ concentrations very similar to those in a 1-D model. We generalise this result in section 6.3 , below, but first consider higher $\mathrm{NO}_{\mathrm{x}}$ scenarios.

\subsection{Medium to high $\left[\mathrm{NO}_{\mathrm{x}}\right]$ conditions}

The comparison between CiTTyCAT and the 1-D model is repeated with the same model set up, but with NO emissions increased by an order of magnitude (Fig. 7). As such an increase NO emission would result in a greater ozone production potential, the initial $\mathrm{O}_{3}$ mixing ratio is set at an increased value of $60 \mathrm{ppbv}$, in line with studies measuring rural ozone concentrations close to an urban $\mathrm{NO}_{\mathrm{x}}$ source (e.g. Murphy et al, 2007; Fuentes et al, 2007). The inter-model comparison of mixing ratios of $\mathrm{NO}_{2}, \mathrm{NO}$, $\mathrm{NO}_{y}$ and $\mathrm{O}_{3}$ in Fig. 7 shows a similar level of agreement between the box and 1-D model as was seen in the runs under low- $\left[\mathrm{NO}_{\mathrm{x}}\right]$ conditions. Only $\mathrm{O}_{3}$ mixing ratios show a substantial discrepancy between the models, although the NO discrepancy has also increased slightly. Once again, removing dry deposition as a sink, largely eliminates the difference in the end-of-night mixing ratios for $\mathrm{NO}_{y}$ and $\mathrm{O}_{3}$ between the box and 1-D models.

As for the low- $\left[\mathrm{NO}_{\mathrm{x}}\right]$ scenario, reducing the $\mathrm{O}_{3}$ deposition velocity in CiTTyCAT, this time to $0.19 \mathrm{~cm} \mathrm{~s}^{-1}$, gives a very good fit to the $1-\mathrm{D}$ model $\mathrm{O}_{3}$ concentration. Compared to the low- $\left[\mathrm{NO}_{\mathrm{x}}\right]$ scenario, the departure for $\mathrm{NO}_{2}$ is increased, with CiTTyCAT $\mathrm{NO}_{2}$ mixing ratios now $24 \%$ less than those in the 1-D model. Furthermore, in this mid- $\left[\mathrm{NO}_{\mathrm{x}}\right]$ scenario, $\mathrm{NO}_{3}$ mixing ratios varying from $<1$ pptv at $1 \mathrm{~m}$ to $>200 \mathrm{pptv}$ at $200 \mathrm{~m}$ are generated in the 1-D model. When combined with a likely layer of high $[\mathrm{OH}]$ near the surface, following Geyer and Stutz (2004b), there is clearly scope for considerable departures in oxidation behaviour between CiTTyCAT and the 1-D model. 
Therefore, whilst the approach of modifying deposition velocities in the box model may be sufficient to effectively model daybreak NBL concentrations of $\mathrm{O}_{3}$, $\mathrm{NO}$ and $\mathrm{NO}_{2}$ in this scenario, box modelled daybreak concentrations of other species may only be treated with confidence at low $\left[\mathrm{NO}_{\mathrm{x}}\right]$, such as that observed during OP3-1.

Increasing NO emissions by an additional order of magnitude to $5.6 \times 10^{11}$ molecules $\mathrm{cm}^{-2} \mathrm{~s}^{-1}$, yields very substantial differences between the two models, even when dry deposition is turned off. These differences are particularly evident in the ozone concentration; the high $[\mathrm{NO}]$ in this scenario allows rapid ozone loss to proceed via reaction R1. However in the 1-D model NO is concentrated near the surface, leading to near-total depletion of $\mathrm{O}_{3}$ near the surface, but the rate of ozone loss in the 1-D model is limited by the rate of transport of ozone to the surface, leading to substantial differences in ozone loss rate, and hence ambient $\left[\mathrm{O}_{3}\right]$, compared to the box model.

\subsection{Generalised fit for low $\left[\mathrm{NO}_{\mathrm{x}}\right]$ conditions}

The box model is clearly inappropriate for modelling $\mathrm{NO}_{\mathrm{x}}$ and $\mathrm{O}_{3}$ chemistry in the stable NBL under high $\left[\mathrm{NO}_{\mathrm{x}}\right]$ conditions. The only way to account for such modifications of the chemistry would be to define effective reaction rates, following e.g. Galmarini et al (1997). However such parameterisations require detailed knowledge of the distribution of species within the boundary layer, making this approach tied to either 1-D modelling or vertically-resolved measurements throughout the NBL. In section 6.1 it was shown that, under low $\left[\mathrm{NO}_{\mathrm{x}}\right]$, it is possible to impose agreement between the box model and the 1-D model by modifying the ozone deposition velocity in the box model. This approach extends the deposition velocity definition to include the reduced mixing within the NBL, resulting in an effective deposition velocity. As the modification to the deposition velocity required will clearly depend upon the $K$ profile used, an empirical relation is developed to describe this dependence. The theory used to describe the $K$ profile in section 5 (Seinfeld and Pandis, 2006) produces a characteristic profile shape for a stable atmosphere, therefore what is of interest here is the magnitude of the $K$ profile. From equations 5 and 6 the $K$ profile is proportional to $u^{*} \times L$. As $u^{*}$ and $L$ are commonly calculated statistics to describe the atmospheric stability, it is convenient to use them to describe the effective mixing rate in the box model.

Figure 8 shows how the fitted ozone deposition velocity for the box model $\left(V_{b}\right)$ varies with the natural $\log$ of $u^{*} \times L$, when the ozone deposition velocity in the $1-\mathrm{D}$ model $\left(V_{c}\right)$ is $0.6 \mathrm{cms}^{-1}$. The equation of the line in Fig 8 .,

$$
V_{b}=0.095 \ln \left(u^{*} \times L\right)+0.27,
$$

only holds when $V_{c}=0.6 \mathrm{~cm} \mathrm{~s}^{-1}$. However, by repeating the process with $V_{c}$ varying from $0.4-1.2 \mathrm{~cm} \mathrm{~s}^{-1}$, expressions for both the gradient and the intercept were developed by plotting them against $V_{c}$. We can therefore relate the modified $\left(V_{b}\right)$ and unmodified $\left(V_{c}\right)$ deposition velocity:

$$
V_{b}=m \ln \left(u^{*} \times L\right)+c \quad 0.4 \leq V_{c} \leq 1.2 \mathrm{~cm} \mathrm{~s}^{-1},\left[\mathrm{NO}_{\mathrm{x}}\right]<1 \mathrm{ppbv},\left[\mathrm{O}_{3}\right]>1 \mathrm{ppbv}
$$

Where the gradient, $m$, is

$$
m=0.066 \ln \left(V_{c}\right)+0.13
$$

and the intercept, $c$, is,

$$
c=0.12 \ln \left(V_{c}\right)+0.33
$$




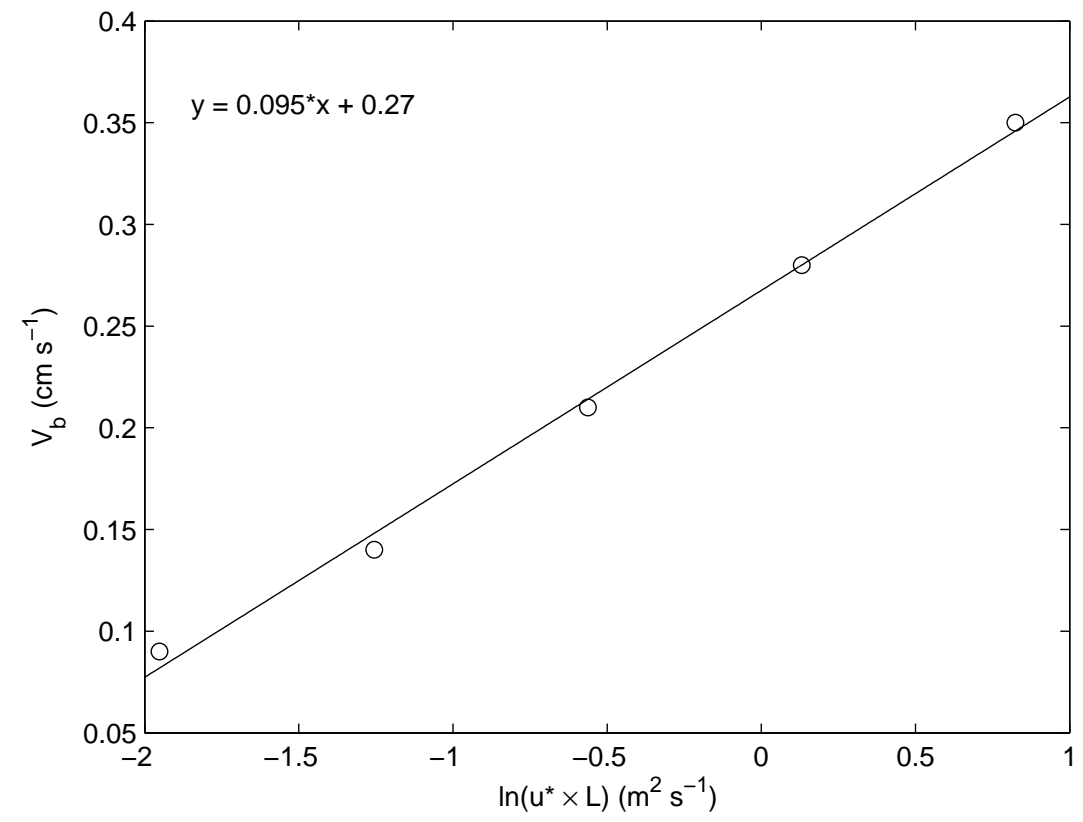

Figure 8: Modified ozone deposition velocity for the box model $\left(V_{b}\right)$ as a function of the natural $\log$ of $u^{*} \times L$, when the ozone deposition velocity in the 1-D model $\left(V_{c}\right)$ is $0.6 \mathrm{~cm} \mathrm{~s}^{-1}$. 

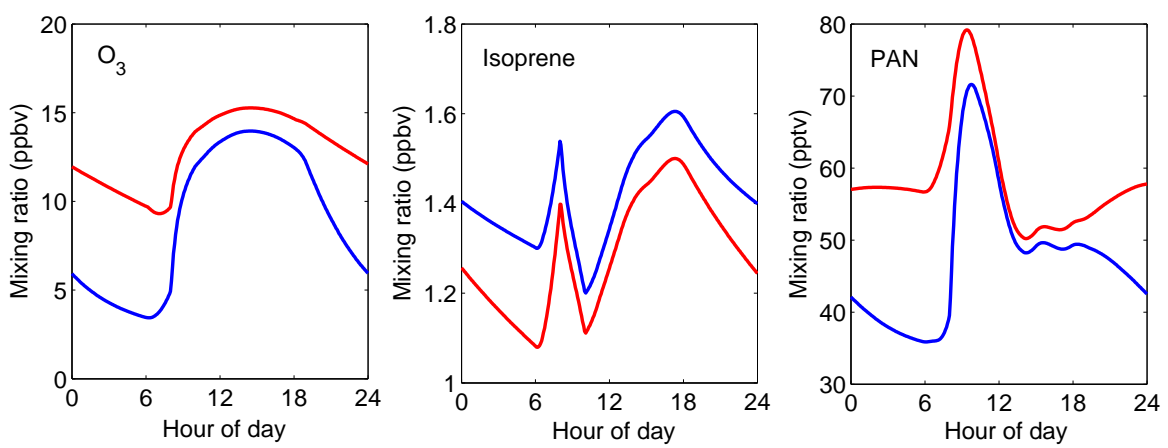

Figure 9: Result of using an effective $\mathrm{O}_{3}$ deposition velocity (65\% reduction) in CiTTyCAT (red line), compared to the default CiTTyCAT run shown in Fig. 1 (blue line) for $\mathrm{O}_{3}$ (left), isoprene (centre) and PAN (right).

The friction velocity, $u^{*}$, is given in units of $\mathrm{ms}^{-1}$, and the Monin-Obukhov length, $L$, is in units of $\mathrm{m}$. Equations 8 to 10 can be used to estimate an appropriate adjustment for the night-time deposition of ozone in box models in order to account for the effects of limited mixing, under low $\left[\mathrm{NO}_{\mathrm{x}}\right]$ conditions.

It is important to note that the low-to-medium $\left[\mathrm{NO}_{\mathrm{x}}\right]$ conditions under which equation 8 holds are influenced by the emissions, the deposition rate and the mixing height. Therefore it is the ambient concentrations which define low $\mathrm{NO}_{\mathrm{x}}$, not the emission rate. Low $\left[\mathrm{NO}_{\mathrm{x}}\right]$ conditions are considered to be those where the $\mathrm{NO}_{\mathrm{x}}$ mixing ratio is $<1 \mathrm{ppbv}$. Additionally equation 8 does not hold in situations where $\mathrm{O}_{3}$ is almost completely depleted at night, either by deposition or by NO titration.

Applying equations 8-10 for the conditions prevalent during OP3 yields a $V_{b}$ which is $65 \%$ smaller than $V_{c}$. To test the importance of using an effective deposition velocity, the CiTTyCAT model run shown in Fig. 1 was repeated using this value of $V_{b}$. The result is compared with the original model run in Fig. 9. No comparison with measurements is made here as the original model run was optimised to agree with the daytime measurements by varying the emissions (see Pugh et al, 2010), therefore a measurement comparison would be misleading in this instance. A $9 \%$ increase in the peak daytime ozone concentration is calculated. The change in the oxidant budget leads to a $7 \%$ reduction in the peak isoprene mixing ratio and an $11 \%$ increase in the peak PAN mixing ratio. The sharp drop in PAN at midday is due to the loss of reactive nitrogen (particularly isoprene nitrates) via wet deposition, reducing PAN formation. Although, as mentioned previously, night-time rainfall was limited during the study period, afternoon rainfall was often substantial (see Hewitt et al, 2010). On days where wet deposition does not occur the increase in PAN is likely to be larger.

\subsection{Application of $\mathrm{O}_{3}$ parametrisation in other models}

The $\mathrm{O}_{3}$ deposition velocity parametrisation developed in Section 6.3 may be directly applied in other box models studying the boundary layer under low- $\mathrm{NO}_{\mathrm{x}}$ conditions. The parametrisation could also be applied to global climate-chemistry models with limited vertical resolution near the surface, if they use a bulk mixing approach within the NBL. For those global climate-chemistry models which use a more complex ap- 
proach to modelling the NBL, between the complexity of the box model and 1-D model approaches used in this paper (for instance a $\mathrm{K}$ profile with a limited number of levels), the conclusions of this work will still apply. In these cases we suggest that modellers must use their own judgement to assess whether their PBL scheme is capable of capturing sufficiently the type of concentration gradients resolved by the 1-D model herein. Should the model resolution be too coarse to capture these gradients, we suggest applying the parametrisation only in the lowermost layer of the model, where the concentration gradient of ozone is steepest. The parameters $\mathrm{L}$ and $\mathrm{u}^{*}$ must be available within the model. We recommend that any implementation in a global model is tested against the case presented in this paper, using a single-column implementation of the model to cover the NBL. We have included in the Supplementary Information details of the 1-D model concentrations with which satisfactory agreement must be achieved.

\section{Summary}

The CiTTyCAT box model is unable to replicate night-time measurements made at $5 \mathrm{~m}$ above ground level due to stratification within the nocturnal boundary layer. However a one-dimensional vertical transport model is able to reproduce many of the salient features of the measurements, especially the elevated 5-m NO concentrations in conjunction with relatively low $\mathrm{NO}_{2}$ concentrations (compared to the $\left[\mathrm{NO}_{2}\right]$ expected based upon the $\mathrm{NO}$ and $\mathrm{O}_{3}$ concentrations alone).

Comparison of average NBL concentrations of $\mathrm{NO}, \mathrm{NO}_{2}$ and $\mathrm{O}_{3}$ between CiTTyCAT and the 1-D model show that CiTTyCAT is able to generate reasonable values for these tracers at the end of the night under low $\left[\mathrm{NO}_{\mathrm{x}}\right]$ conditions. However the fit to $\left[\mathrm{O}_{3}\right]$ can be greatly improved by taking account for the effect of the nocturnal vertical concentration profile of $\mathrm{O}_{3}$ on its deposition velocity. A generalised equation to define an effective night-time $\mathrm{O}_{3}$ deposition velocity for box models is presented. Use of an effective $\mathrm{O}_{3}$ deposition velocity during the night results in notable changes in concentrations during the following day for important species for atmospheric chemistry, such as ozone, isoprene and PAN. However, under high $\left[\mathrm{NO}_{\mathrm{x}}\right]$, the vertical variation in chemistry renders the box model inappropriate for modelling night-time concentrations.

The parameterisation we have developed in section 6.3 would also be suitable for global climate-chemistry models with limited vertical resolution near the surface, if they use a bulk mixing approach within the NBL. For those global climate-chemistry models which use a more complex approach to modelling the NBL, between the complexity of the box model and 1-D model approaches used in this paper (for instance a $K$ profile with a limited number of levels), the conclusions of this work will still apply. However a different correcting parameterisation for the ozone deposition velocity at low $\left[\mathrm{NO}_{\mathrm{x}}\right]$ would need to be formulated according to the specific characteristics of the individual model.

\section{Acknowledgements}

This work was funded by the Natural Environment Research Council (award NE/D0 02117/1). The authors would like to thank the Malaysian and Sabah Governments for their permission to conduct research in Malaysia; the Malaysian Meteorological De- 
partment for access to the Bukit Atur Global Atmosphere Watch station; Waidi Sinun of Yayasan Sabah and his staff, Glen Reynolds of the Royal Society's South East Asian Rainforest Research Programme and his staff, and Nick Chappell and Brian Davison of Lancaster University for logistical support at the Danum Valley Field Centre. They also thank two anonymous reviewers for their helpful and constructive comments. This is paper number 519 of the Royal Society's South East Asian Rainforest Research Programme.

\section{References}

Acevedo OC, Moraes OLL, Degrazia GA, Medeiros LE (2006) Intermittency and the exchange of scalars in the nocturnal surface layer. Bound-Lay Meteorol 119(1):4155, DOI 10.1007/s10546-005-9019-3

ApSimon H, Barker B, Kayin S (1994) Modelling studies of the atmospheric release and transport of ammonia in anticyclonic episodes. Atmos Environ 28(4):665-678

Aumont B, Chervier F, Laval S (2003) Contribution of HONO sources to the $\mathrm{NO}_{x} / \mathrm{HO}_{x} / \mathrm{O}_{3}$ chemistry in the polluted boundary layer. Atmos Environ 37(4):487498

Biesenthal T, Bottenheim J, Shepson P, Brickell P (1998) The chemistry of biogenic hydrocarbons at a rural site in eastern Canada. J Geophys Res - Atmos 103(D19):25,487-25,498, International Workshop on Biogenic Hydrocarbons in the Atmospheric Boundary Layer, Charlottesville, Virginia, Aug, 1997

Brost R, Delany A, Huebert B (1988) Numerical modeling of concentrations and fluxes of $\mathrm{HNO}_{3}, \mathrm{NH}_{3}$, and $\mathrm{NH}_{4} \mathrm{NO}_{3}$ near the surface. J Geophys Res - Atmos 93(D6):71377152

Brown SS, Dube WP, Osthoff HD, Wolfe DE, Angevine WM, Ravishankara AR (2007) High resolution vertical distributions of $\mathrm{NO}_{3}$ and $\mathrm{N}_{2} \mathrm{O}_{5}$ through the nocturnal boundary layer. Atmos Chem Phys 7:139-149

Businger J, Wyngaard J, Izumi Y, Bradley E (1971) Flux-Profile Relationships in Atmospheric Surface Layer. J Atmos Sci 28(2):181-\&

Coyle M, Fowler D, Nemitz E, Philips G, Storeton-West R, Thomas R (2006) Field measurements of the ozone flux to vegetation. In: Ozone Umbrella: Effects of Ground-level Ozone on (Upland) Vegetation in the UK., Centre of Ecology and Hydrology, UK, CEH C02158 Report No. AS 06/02., p 68104

Cros B, Fontan J, Minga A, Helas G, Nganga D, Delmas R, Chapuis A, Benech B, Druilhet A, Andreae M (1992) Vertical profiles of ozone between 0 metres and 400 metres in and above the African equatorial forest. J Geophys Res-Atm 97(D12):12,877-12,887

Daescu D, Sandu A, Carmichael G (2003) Direct and adjoint sensitivity analysis of chemical kinetic systems with kpp: Ii - validation and numerical experiments. Atmospheric Environment 37:5097-5114 
Damian V, Sandu A, Damian M, Potra F, Carmichael G (2002) The kinetic preprocessor kpp - a software environment for solving chemical kinetics. Computers and Chemical Engineering 26(11):1567-1579

Donovan R, Hope E, Owen S, Mackenzie A, Hewitt C (2005) Development and application of an urban tree air quality score for photochemical pollution episodes using the birmingham, united kingdom, area as a case study. Environ Sci Technol 39:6730-6738

Emmerson K, MacKenzie A, Owen S, Evans M, Shallcross D (2004) A lagrangian model with simple primary and secondary aerosol scheme 1: comparison with uk $\mathrm{pm}_{10}$ data. Atmos Chem Phys 4:2161-2170

Evans M, Shallcross D, Law K, Wild J, Simmonds P, Spain T, Berrisford P, Methven J, Lewis A, McQuaid J, Pilling M, Bandy B, Penkett S, Pyle J (2000) Evaluation of a Lagrangian box model using field measurements from EASE (Eastern Atlantic Summer Experiment) 1996. Atmos Environ 34(23):3843-3863

Faloona I, Tan D, Brune W, Hurst J, Barket D, Couch T, Shepson P, Apel E, Riemer D, Thornberry T, Carroll M, Sillman S, Keeler G, Sagady J, Hooper D, Paterson K (2001) Nighttime observations of anomalously high levels of hydroxyl radicals above a deciduous forest canopy. J Geophys Res - Atmos 106(D20):24,315-24,333

Fan S, Wofsy S, Bakwin P, Jacob D, Fitzjarrald D (1990) Atmosphere-biosphere exchange of $\mathrm{CO}_{2}$ and $\mathrm{O}_{3}$ in the Central-Amazon-Forest. J Geophys Res - Atmos 95(D10):16,851-16,864

Fitzjarrald D, Lenschow D (1983) Mean concentration and flux profiles for chemically reactive species in the atmospheric surface-layer. Atmos Environ 17(12):2505-2512

Fitzjarrald D, Moore K (1990) Mechanisms of nocturnal exchange between the rainforest and the atmosphere. J Geophys Res - Atmos 95(D10):16,839-16,850

Fowler D, Pilegaard K, Sutton MA, Ambus P, Raivonen M, Duyzer J, Simpson D, Fagerli H, Fuzzi S, Schjoerring JK, Granier C, Neftel A, Isaksen ISA, Laj P, Maione M, Monks PS, Burkhardt J, Daemmgen U, Neirynck J, Personne E, Wichink-Kruit R, Butterbach-Bahl K, Flechard C, Tuovinen JP, Coyle M, Gerosa G, Loubet B, Altimir N, Gruenhage L, Ammann C, Cieslik S, Paoletti E, Mikkelsen TN, RoPoulsen H, Cellier P, Cape JN, Horvath L, Loreto F, Niinemets U, Palmer PI, Rinne J, Misztal P, Nemitz E, Nilsson D, Pryor S, Gallagher MW, Vesala T, Skiba U, Brueggemann N, Zechmeister-Boltenstern S, Williams J, O'Dowd C, Facchini MC, de Leeuw G, Flossman A, Chaumerliac N, Erisman JW (2009) Atmospheric composition change: Ecosystems-Atmosphere interactions. Atmos Environ 43(33, Sp. Iss. SI):5193-5267, DOI 10.1016/j.atmosenv.2009.07.068

Fuentes JD, Wang D, Bowling DR, Potosnak M, Monson RK, Goliff WS, Stockwell WR (2007) Biogenic hydrocarbon chemistry within and above a mixed deciduous forest. J Atmos Chem 56(2):165-185, DOI 10.1007/s10874-006-9048-4

Galmarini S, Duynkerke P, deArellano I (1997) Evolution of nitrogen oxide chemistry in the nocturnal boundary layer. J Appl Meteorol 36(7):943-957 
Gao W, Wesely M (1994) Numerical modeling of the turbulent fluxes of chemically reactive trace gases in the atmospheric boundary-layer. J Appl Meteorol 33(7):835847

Gao W, Wesely M, Doskey P (1993) Numerical modeling of the trubulent-diffusion and chemistry of $\mathrm{NO}_{\mathrm{x}}, \mathrm{O}_{3}$, isoprene, and other reactive trace gases in and above a forest canopy. J Geophys Res-Atmos 98(D10):18,339-18,353

Geyer A, Stutz J (2004a) Vertical profiles of $\mathrm{NO}_{3}, \mathrm{~N}_{2} \mathrm{O}_{5}, \mathrm{O}_{3}$, and $\mathrm{NO}_{\mathrm{x}} \mathrm{x}$ in the nocturnal boundary layer: 2. Model studies on the altitude dependence of composition and chemistry. J Geophys Res - Atmos 109(D12), DOI 10.1029/2003JD004211

Geyer A, Stutz J (2004b) The vertical structure of $\mathrm{OH}-\mathrm{HO}_{2}-\mathrm{RO}_{2}$ chemistry in the nocturnal boundary layer: A one-dimensional model study. J Geophys Res 109(D16), DOI 10.1029/2003JD004425

Glaser K, Vogt U, Baumbach G, Volz-Thomas A, Geiss H (2003) Vertical profiles of $\mathrm{O}_{3}, \mathrm{NO}_{2}, \mathrm{NO}_{\mathrm{x}}, \mathrm{VOC}$, and meteorological parameters during the Berlin Ozone Experiment (BERLIOZ) campaign. J Geophys Res-Atm 108(D4), DOI 10.1029/2001JD002475

Guenther A, Karl T, Harley P, Wiedinmyer C, Palmer PI, Geron C (2006) Estimates of global terrestrial isoprene emissions using MEGAN (Model of Emissions of Gases and Aerosols from Nature). Atmos Chem Phys 6:3181-3210

Gusten H, Heinrich G, Sprung D (1998) Nocturnal depletion of ozone in the Upper Rhine Valley. Atmos Environ 32(7):1195-1202

Hamba F (1987) Statistical-analysis of chemically reacting passive scalars in turbulent shear flows. J Phys Soc Jpn 56(1):79-96

Hamer P, Shallcross D (2007) Modelling the impact of oxygenated VOC and meteorology upon the boundary layer photochemistry at the South Pole. Atmos Sci Lett $8: 14-20$

Hewitt CN, Lee JD, MacKenzie AR, Barkley MP, Carslaw N, Carver GD, Chappell NA, Coe H, Collier C, Commane R, Davies F, Davison B, DiCarlo P, Di Marco CF, Dorsey JR, Edwards PM, Evans MJ, Fowler D, Furneaux KL, Gallagher M, Guenther A, Heard DE, Helfter C, Hopkins J, Ingham T, Irwin M, Jones C, Karunaharan A, Langford B, Lewis AC, Lim SF, MacDonald SM, Mahajan AS, Malpass S, McFiggans G, Mills G, Misztal P, Moller S, Monks PS, Nemitz E, Nicolas-Perea V, Oetjen H, Oram DE, Palmer PI, Phillips GJ, Pike R, Plane JMC, Pugh T, Pyle JA, Reeves CE, Robinson NH, Stewart D, Stone D, Whalley LK, Yin X (2010) Overview: oxidant and particle photochemical processes above a south-east asian tropical rainforest (the op3 project): introduction, rationale, location characteristics and tools. Atmos Chem Phys 10(1):169-199, URL http://www.atmos-chemphys.net/10/169/2010/

Hewitt CN, MacKenzie AR, Di Carlo P, Di Marco CF, Dorsey JR, Evans M, Fowler D, Gallagher MW, Hopkins JR, Jones CE, Langford B, Lee JD, Lewis AC, Lim SF, McQuaid J, Misztal P, Moller SJ, Monks PS, Nemitz E, Oram DE, Owen SM, Phillips GJ, Pugh TAM, Pyle JA, Reeves CE, Ryder J, Siong J, Skiba U, Stewart DJ (2009) Nitrogen management is essential to prevent tropical oil palm plantations 
from causing ground-level ozone pollution. Proc Nat Acad Sci USA 106(44):18,44718,451, DOI 10.1073/pnas.0907541106

Horowitz LW, Fiore AM, Milly GP, Cohen RC, Perring A, Wooldridge PJ, Hess PG, Emmons LK, Lamarque JF (2007) Observational constraints on the chemistry of isoprene nitrates over the eastern United States. J Geophys Res 112(D12), DOI 10.1029/2006JD007747

Hov O (1983) One-dimensional vertical model for ozone and other gases in the atmospheric boundary-layer. Atmos Environ 17(3):535-549

Kerkweg A, Buchholz J, Ganzeveld L, Pozzer A, Tost H, Joeckel P (2006) Technical note: An implementation of the dry removal processes DRY DEPosition and SEDImentation in the modular earth submodel system (MESSy). Atmos Chem Phys 6:4617-4632

Kleffmann J (2007) Daytime sources of nitrous acid (HONO) in the atmospheric boundary layer. ChemPhysChem 8(8):1137-1144, DOI 10.1002/cphc.200700016

Kleffmann J, Becker K, Wiesen P (1998) Heterogeneous $\mathrm{NO}_{2}$ conversion processes on acid surfaces: Possible atmospheric implications. Atmos Environ 32(16):2721-2729

Lowe D, Topping D, McFiggans G (2009) Modelling multi-phase halogen chemistry in the remote marine boundary layer: investigation of the influence of aerosol size resolution on predicted gas- and condensed-phase chemistry. Atmos Chem Phys 9(14):4559-4573

Matsuda K, Watanabe I, Wingpud V (2005) Ozone dry deposition above a tropical forest in the dry season in northern Thailand. Atmos Environ 39(14):2571-2577, DOI 10.1016/j.atmosenv.2005.01.011

Michou M, Laville P, Serca D, Fotiadi A, Bouchou P, Peuch V (2005) Measured and modeled dry deposition velocities over the ESCOMPTE area. Atmos Res 74(1-4):89116, DOI 10.1016/j.atmosres.2004.04.011

Mihele C, Hastie D (2003) Radical chemistry at a forested continental site: Results from the PROPHET 1997 campaign. J Geophys Res - Atmos 108(D15), DOI 10.1029/2002JD002888

Monks P (2005) Gas-phase radical chemistry in the troposphere. Chemical Society Reviews 34(5):376-395, DOI 10.1039/b307982c

Murphy JG, Day DA, Cleary PA, Wooldridge PJ, Millet DB, Goldstein AH, Cohen RC (2007) The weekend effect within and downwind of Sacramento - Part 1: Observations of ozone, nitrogen oxides, and VOC reactivity. Atmos Chem Phys $7(20): 5327-5339$

Pearson G, Davies F, Collier C (2010) Remote sensing of the tropical rain forest boundary layer using pulsed doppler lidar. Atmos Chem Phys Discuss 10(2):50215049, URL http://www.atmos-chem-phys-discuss.net/10/5021/2010/

Pike R, Lee J, Young P, Moller S, Carver G, Yang X, Misztal P, Langford B, Stewart D, Reeves C, Hewitt C, Pyle J (2009) Can a gcm mechanism reproduce no, no2 and $\mathrm{O}_{3}$ data above a tropical rainforest? Atmos Chem Phys Discuss pp 27,611-27,648 
Pisano J, McKendry I, Steyn D, Hastie D (1997) Vertical nitrogen dioxide and ozone concentrations measured from a tethered balloon in the Lower Fraser Valley. Atmos Environ 31(14):2071-2078

Pugh TAM, MacKenzie AR, Hewitt CN, Langford B, Edwards PM, Furneaux KL, Heard DE, Hopkins JR, Jones CE, Karunaharan A, Lee J, Mills G, Misztal P, Moller S, Monks PS, Whalley LK (2010) Simulating atmospheric composition over a South-East Asian tropical rainforest: performance of a chemistry box model. Atmos Chem Phys 10(1):279-298

Read KA, Mahajan AS, Carpenter LJ, Evans MJ, Faria BVE, Heard DE, Hopkins JR, Lee JD, Moller SJ, Lewis AC, Mendes L, McQuaid JB, Oetjen H, SaizLopez A, Pilling MJ, Plane JMC (2008) Extensive halogen-mediated ozone destruction over the tropical Atlantic Ocean. Naturepug 453(7199):1232-1235, DOI $10.1038 /$ nature07035

Real E, Law KS, Weinzierl B, Fiebig M, Petzold A, Wild O, Methven J, Arnold S, Stohl A, Huntrieser H, Roiger A, Schlager H, Stewart D, Avery M, Sachse G, Browell E, Ferrare R, Blake D (2007) Processes influencing ozone levels in Alaskan forest fire plumes during long-range transport over the North Atlantic. J Geophys Res Atmos 112(D10), DOI 10.1029/2006JD007576

Real E, Law KS, Schlager H, Roiger A, Huntrieser H, Methven J, Cain M, Holloway J, Neuman JA, Ryerson T, Flocke F, de Gouw J, Atlas E, Donnelly S, Parrish D (2008) Lagrangian analysis of low altitude anthropogenic plume processing across the North Atlantic. Atmos Chem Phys 8(24):7737-7754

Rummel U, Ammann C, Kirkman GA, Moura MAL, Foken T, Andreae MO, Meixner FX (2007) Seasonal variation of ozone deposition to a tropical rain forest in southwest Amazonia. Atmos Chem Phys 7(20):5415-5435

Ryder J, Lowe D, McFiggans G, Nemitz E (2010) Application of a coupled chemistry and deposition model to simulate the effect of gas / aerosol partitioning on sizesegregated aerosol fluxes above and within a heathland canopy. in preparation

Sandu A, Daescu D, Carmichael G (2003) Direct and adjoint sensitivity analysis of chemical kinetic systems with kpp: I - theory and software tools. Atmospheric Environment 37:5083-5096

Seinfeld J, Pandis S (2006) Atmospheric chemistry and physics: From air pollution to climate change, 2nd edn. Wiley-interscience, New Jersey, USA

Strong J, Whyatt JD, Hewitt CN, Derwent RG (2009) Development and application of a Lagrangian model to determine the origins of ozone episodes in the UK. Atmos Environ, in press DOI 10.1016/j.atmosenv.2009.11.019

Stutz J, Alicke B, Ackermann R, Geyer A, White A, Williams E (2004) Vertical profiles of $\mathrm{NO}_{3}, \mathrm{~N}_{2} \mathrm{O}_{5}, \mathrm{O}_{3}$, and $\mathrm{NO}_{x}$ in the nocturnal boundary layer: 1. Observations during the Texas Air Quality Study 2000. J Geophys Res-Atmos 109(D16), DOI 10.1029/2004JD005216

Thompson A, Lenschow D (1984) Mean profiles of trace reactive species in the unpolluted marine surface-layer. J Geophys Res - Atmos 89(ND3):4788-4796 
Toyota K, Kanaya Y, Takahashi M, Akimoto H (2004) A box model study on photochemical interactions between VOCs and reactive halogen species in the marine boundary layer. Atmos CHem Phys 4:1961-1987

Trebs I, Lara L, Zeri L, Gatti L, Artaxo P, Dlugi R, Slanina J, Andreae M, Meixner F (2006) Dry and wet deposition of inorganic nitrogen compounds to a tropical pasture site (Rondonia, Brazil). Atmos Chem Phys 6:447-469

Vila-Guerau de Arellano J (2003) Bridging the gap between atmospheric physics and chemistry in studies of small-scale turbulence. B Am Meteorol Soc 84(1):51-56, DOI 10.1175/BAMS-84-1-51

Vinuesa J, Vilà-Guerau de Arellano J (2005) Introducing effective reaction rates to account for the inefficient mixing of the convective boundary layer. Atmos Environ 39(3):445-461, DOI 10.1016/j.atmosenv.2004.10.003

Watt S, Wagner-Riddle C, Edwards G, Vet R (2004) Evaluating a flux-gradient approach for flux and deposition velocity of nitrogen dioxide over short-grass surfaces. Atmos Environ 38(17):2619-2626, DOI 10.1016/j.atmossenv.2004.02.021

Wayne R, Barnes I, Biggs P, Burrows J, Canosamas C, Hjorth J, Lebras G, Moortgat G, Perner D, Poulet G, Restelli G, Sidebottom H (1991) The nitrate radical - physics, chemistry, and the atmosphere. Atmos Environ A-Gen 25(1):1-203

Wesely M, Hicks B (2000) A review of the current status of knowledge on dry deposition. Atmos Environ 34(12-14):2261-2282

Wild O, Law K, McKenna D, Bandy B, Penkett S, Pyle J (1996) Photochemical trajectory modeling studies of the North Atlantic region during August 1993. J Geophys Res 101(D22):29,269-29,288

Yienger J, Levy $\mathrm{H}(1995)$ Empirical model of global soil biogenic $\mathrm{NO}_{\mathrm{x}}$ emissions. J Geophys Res 100(D6):11,447-11,464

Zhang L, Vet R, O'Brien JM, Mihele C, Liang Z, Wiebe A (2009) Dry deposition of individual nitrogen species at eight Canadian rural sites. J Geophys Res - Atmos 114, DOI 10.1029/2008JD010640 